\title{
Effects of short-term fasting on cancer treatment
}

\author{
Stefanie de Groot ${ }^{1}$, Hanno Pijl2 ${ }^{2}$ Jacobus J. M. van der Hoeven ${ }^{1}$ and Judith R. Kroep ${ }^{1 *}$
}

\begin{abstract}
Growing preclinical evidence shows that short-term fasting (STF) protects from toxicity while enhancing the efficacy of a variety of chemotherapeutic agents in the treatment of various tumour types. STF reinforces stress resistance of healthy cells, while tumor cells become even more sensitive to toxins, perhaps through shortage of nutrients to satisfy their needs in the context of high proliferation rates and/or loss of flexibility to respond to extreme circumstances. In humans, STF may be a feasible approach to enhance the efficacy and tolerability of chemotherapy. Clinical research evaluating the potential of STF is in its infancy. This review focuses on the molecular background, current knowledge and clinical trials evaluating the effects of STF in cancer treatment. Preliminary data show that STF is safe, but challenging in cancer patients receiving chemotherapy. Ongoing clinical trials need to unravel if STF can also diminish toxicity and increase efficacy of chemotherapeutic regimes in daily practice.
\end{abstract}

Keywords: Short-term fasting, Fasting-mimicking diet, Chemotherapy, Differential stress resistance, Differential stress sensitization, Toxicity

\section{Background}

Chronic caloric restriction reduces and delays cancer incidence, and inhibits tumor progression and metastasis in rodents [1-5]. Accordingly, cancer incidence and mortality are strongly reduced in chronic calorie restricted non-human primates [6]. Studies of long-term calorie restricted human subjects have shown a reduction of metabolic and hormonal factors associated with cancer risk [7-9]. However, chronic caloric restriction is not a feasible clinical intervention. Evident difficulties, such as the long period required to be effective, and unacceptable weight loss [10, 11], hamper clinical application in cancer patients.

Preclinical studies suggest that short-term fasting (STF) protects rodents from toxic effects of chemotherapy, while simultaneously enhances the efficacy of a variety of chemotherapeutic agents in numerous distinct malignancies, e.g. breast cancer, melanoma, neuroblastoma, pancreatic cancer, and colorectal cancer [12]. In distinct strains of mice bearing xenograft malignancies, tumor growth clearly slows down in response to chemotherapy combined with a $24-60 \mathrm{~h}$ fast as compared to treatment with

\footnotetext{
* Correspondence: J.R.Kroep@lumc.nl

'Department of Medical Oncology, Leiden University Medical Center,

Albinusdreef 2, P.O. Box 9600, 2300RC Leiden, The Netherlands

Full list of author information is available at the end of the article
}

chemotherapy alone [13-17]. STF simultaneously protects mice from chemotoxicity as well, because it reinforces stress resistance of healthy cells [17-24]. The distinct response of healthy versus tumor cells to STF is called differential stress resistance (DSR). During nutrient deprivation, healthy cells re-invest energy in maintenance and repair that contribute to resistance to chemotherapy, while tumor cells are unable to slow down growth due to mutations in tumor suppressor genes and mitogenic pathways [19, 25]. Moreover, low serum levels of glucose during STF impose extra stress on tumor cells, as their energy needs under these circumstances are primarily met by means of glycolysis [14]. As a consequence of these differential responses of healthy versus cancer cells to STF, chemotherapy causes more DNA damage and apoptosis in tumor cells, while leaving healthy cells unharmed when it is combined with STF. Thus, STF protects healthy cells against the toxic properties of chemotherapy and renders tumor cells more sensitive, a phenomenon called differential stress sensitization (DSS).

In contrast to most cancer therapies, STF has only mild side effects, such as headaches, dizziness, nausea, weakness and short-term weight loss in humans [26]. Therefore, STF is a promising strategy to enhance the efficacy and tolerability of chemotherapy in cancer

(c) The Author(s). 2019 Open Access This article is distributed under the terms of the Creative Commons Attribution 4.0 International License (http://creativecommons.org/licenses/by/4.0/), which permits unrestricted use, distribution, and 
patients, especially as STF is an affordable and accessible approach and is potentially effective in a wide variety of tumors [12]. However, patients with severe weight loss, sarcopenia, cachexia or malnutrition are probably not good candidates for a STF intervention [27, 28]. Recent guidelines recommend to increase protein and fat consumption in patients with cachexia $[29,30]$. Thus, STF may be particularly useful for relatively fit patients treated with (neo)adjuvant chemotherapy.

This narrative review will cover the current knowledge of the molecular mechanisms explaining "differential stress resistance" of healthy- and cancer cells in response to STF. Moreover, it summarizes the available clinical data reflecting the impact of STF on the effects of chemotherapy in cancer patients. Finally, ongoing clinical studies of the effects of STF in cancer treatment will be critically reviewed.

\section{Differential stress resistance and sensitization in response to STF}

In healthy cells, nutrient deprivation shuts down pathways promoting growth to re-invest energy in maintenance and repair pathways (Fig. 1) [25, 31, 32]. This results in increased cellular protection, contributing to enhanced resistance to distinct stressors including chemotherapy and radiotherapy [19, 33]. In contrast, tumor cells are unable to activate this protective response, due to: 1) uncontrolled activation of growth pathways and self-sufficiency in growth signals caused by oncogenic mutations or autocrine production of growth factors, and 2) loss of anti-proliferative signals due to mutations in tumor suppressor genes [34]. Thus, acquiring the ability to increase growth, tumor cells lose the ability to adapt to extreme environments, including nutrient deprivation. Additionally, the persistent increased growth rate of tumor cells requires abundant nutrients [35]. Therefore, STF increases DSS of tumor cells to several chemotherapeutic agents, radiotherapy and tyrosine kinase inhibitors (TKIs) (Table 1) [12-16, 18-20, 36-40]. Although the exact mechanism of DSR and DSS by STF is unknown, several growth factors and nutrient sensing pathways have been proposed to be key regulators, of which insulin-like growth factor-1 (IGF-1) is the most examined [41-43]. Nutrient sensing pathways are activated or inhibited in response to a low amount of available nutrients and are highly conserved among distinct organisms to overcome periods of famine [44]. During nutrient scarcity, these pathways guide cells to invest energy in repair and maintenance rather than reproduction and growth [45-47], presumably to enhance survival of periods of famine. Analogously, infection-induced anorexia is a common sign of sickness and may be an important strategy for host defence $[48,49]$.

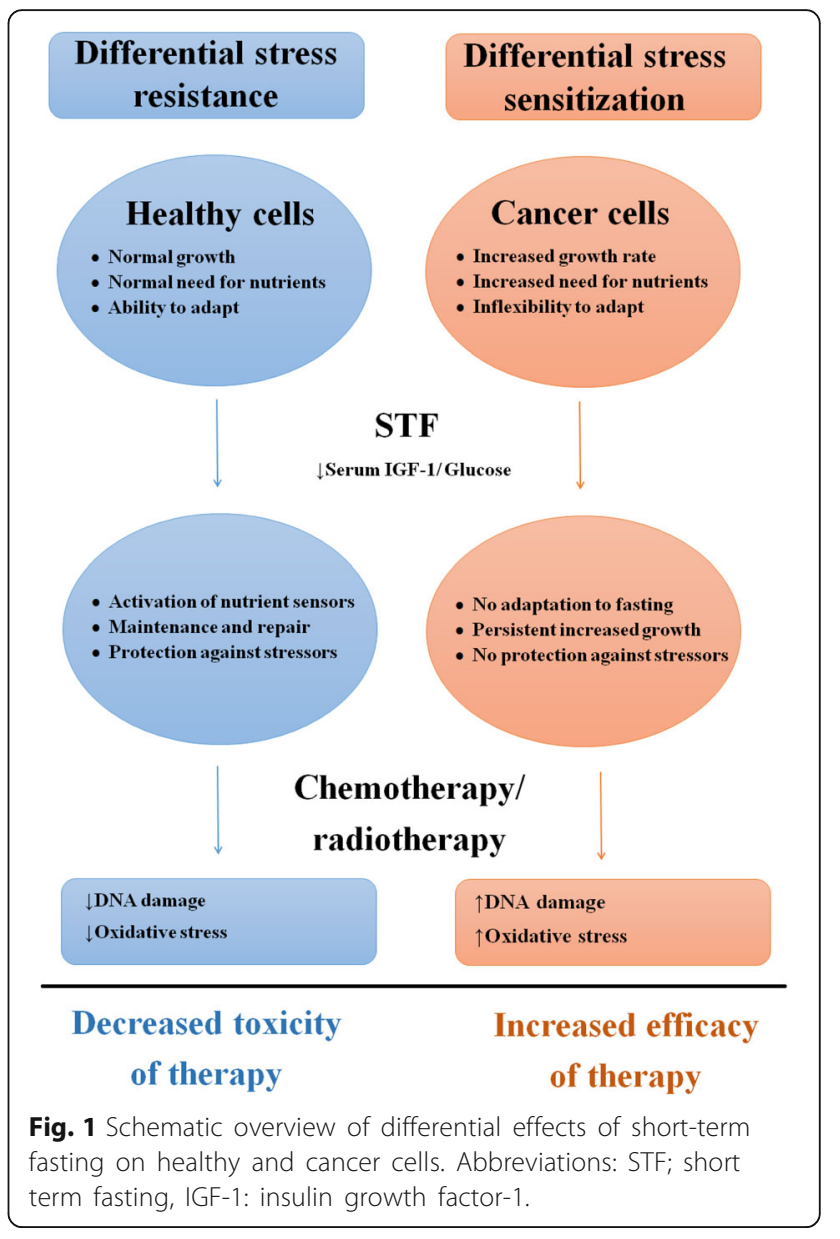

IGF-1 and insulin as key regulators of DSR

IGF-1 and insulin stimulate proliferation and growth and inhibit apoptosis in response to calorie and protein availability through signalling via the IGF-1 receptor (IGF-1R) and insulin receptor isoform A (IR-A), respectively [50-53]. Serum IGF-1 levels decrease during STF [54-56], because low insulin levels cause growth hormone $(\mathrm{GH})$ resistance of the liver, which inhibits hepatic IGF-1 production [54, 57, 58]. Both insulin and IGF-1 activate the Ras/mitogen-activated protein kinase (MAPK) and phosphatidylinositol-3-kinase (PI3K)/Akt pathways. In healthy cells, inhibition of proliferation and/or investment in maintenance may contribute to increased stress resistance. For example, mice with a liver Igf1 gene deletion (LID), which have decreased IGF-1 levels similar to those during STF [59-61], exhibit increased resistance to high doses of various chemotherapeutic agents [42] and this benefit was nullified through IGF-1 administration [12, 42]. Thus, the IGF-1R pathway seems to be a key mediator of stress resistance in response to STF in healthy cells.

During STF, the Ras/MAPK and PI3K/Akt pathways are down-regulated in cancer cells, whereby proliferation 


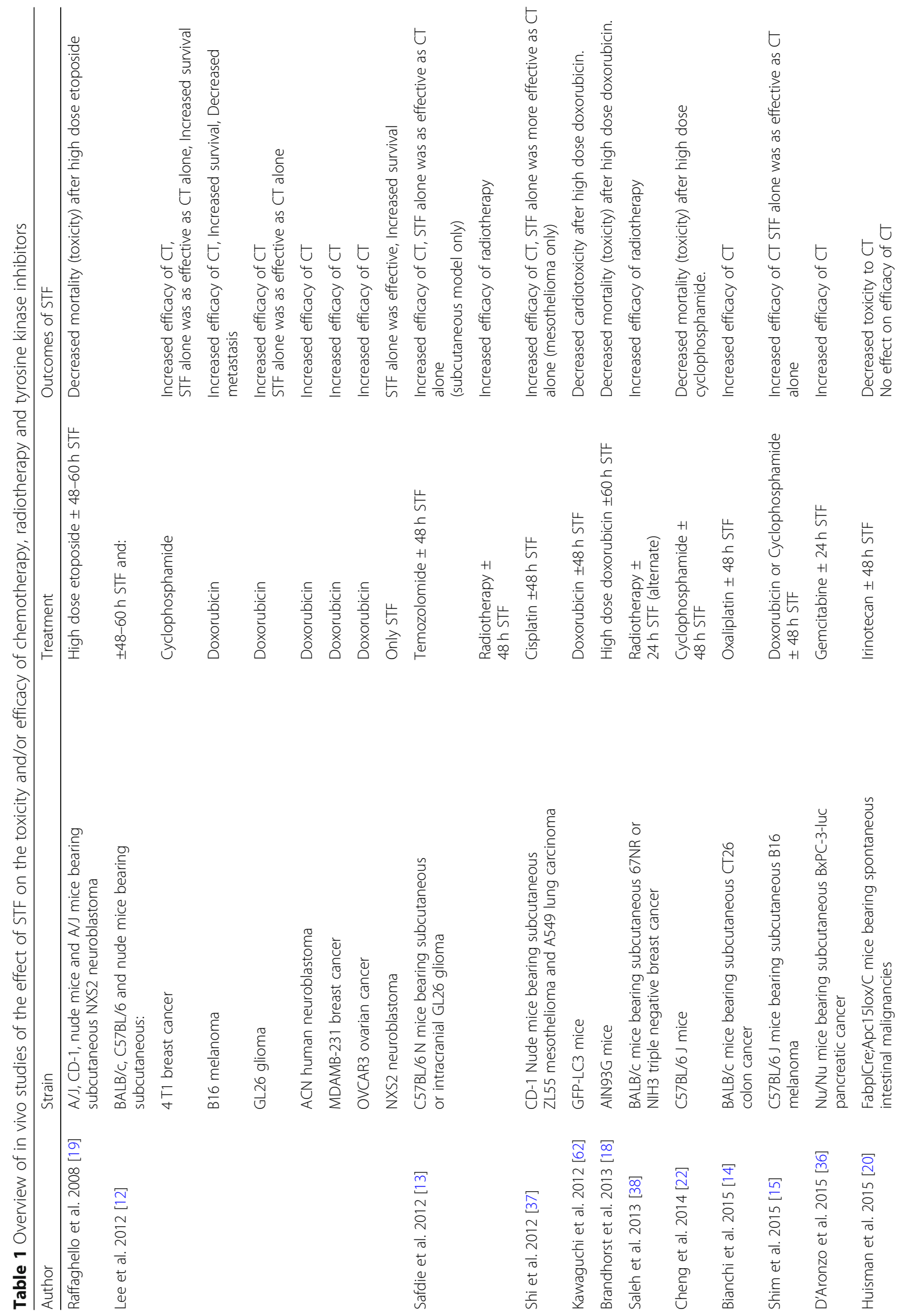




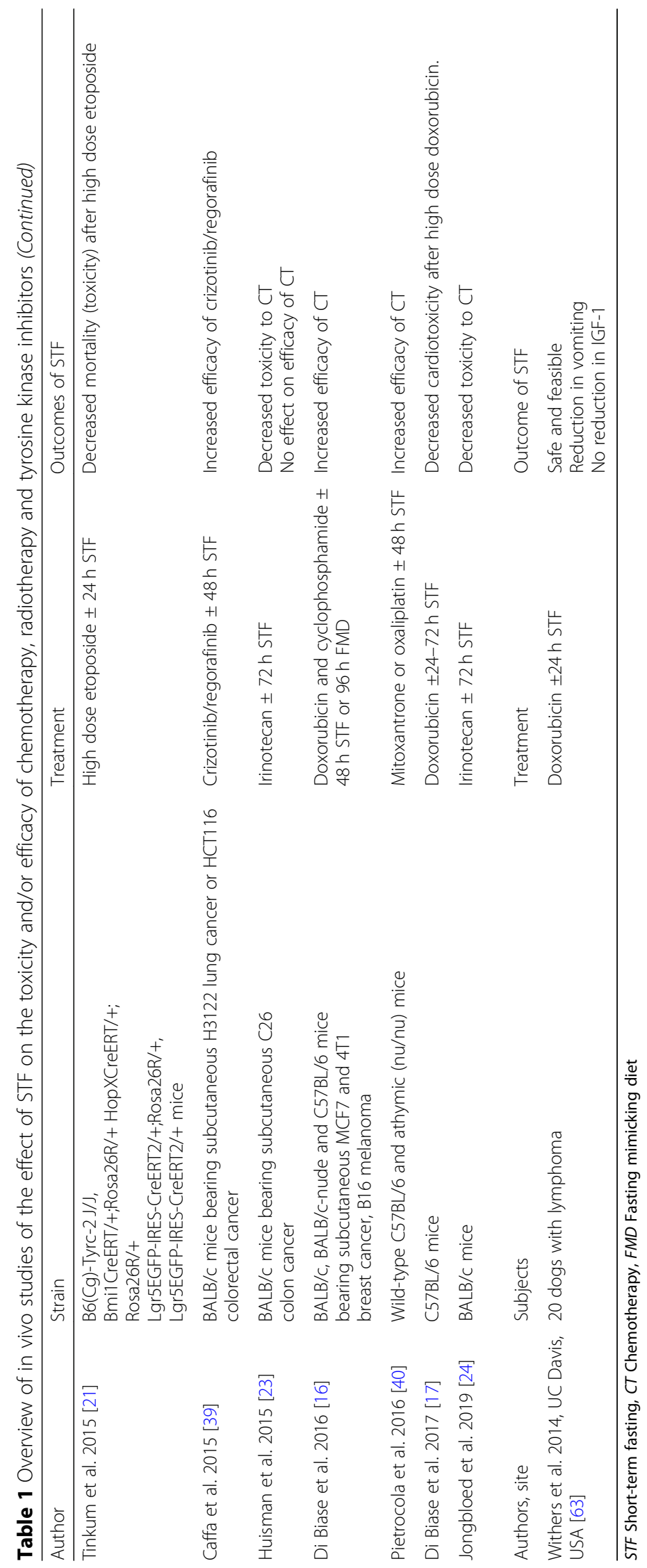


is inhibited [64]. Notably, resistance to the growth limiting effects of STF has been observed in cancer cells carrying mutations that cause a constitutive activation of the PI3K pathway, since these cells proliferate even in the absence of insulin or IGF-1 [65]. Therefore, the IGF-1R pathway is a key mediator of cancer cell growth and cancer resistance to commonly used therapeutics $[42,66,67]$. Thus, the reduction in circulating levels of IGF-1 and insulin during STF may contribute to the anticancer activity as well [68].

\section{AMPK and autophagy}

AMP-activated protein kinase (AMPK) may play a major part in DSR due to STF [69]. AMPK monitors cellular energy levels and becomes activated when ADP:ATP or AMP:ATP ratios in the cell increase [70]. AMPK inhibits energy consuming processes, such as cell proliferation and protein synthesis, and activates energy generating processes, such as glycolysis and fatty acid oxidation. It inhibits cell growth and stimulates autophagy [71]. Autophagy (Greek for "self-eating") is a highly conserved catabolic process among eukaryotes to survive periods of nutrient deprivation. This adaptive response of the cell involves damaged protein and organelle degradation to generate amino acids as an alternative energy source [72, 73]. Activation of AMPK and autophagy seems to play a major part in de protective effects of STF in healthy cells [17].

However, the effects of AMPK activation in distinct tumor cells may vary, as some tumors harbour constitutively active AMPK [74, 75] and others exhibit low AMPK activity [76-78]. Tumors with diminished AMPK activity or autophagy may be highly sensitive to STF, as AMPK activation enhances immune surveillance [40], whereas tumors with highly active AMPK or autophagy may be resistant $[77,79-82]$.

\section{Glucose metabolism and the "Warburg effect"}

During STF, healthy cells, have the metabolic flexibility to cope with nutrient deprivation, since glucose can be replaced by ketone bodies and fatty acids as primary energy source.

In contrast, tumor cells depend on glucose to maintain the high rate of cellular proliferation [83, 84]. Akt stimulates the so called "Warburg effect", characterized by an increased rate of glycolysis rather than oxidative phosphorylation even in the presence of oxygen [83-85]. STF down-regulates anaerobic glycolysis while up-regulating oxidative phosphorylation in tumor cells, and this "anti-Warburg effect" results in oxidative stress and apoptosis [14]. Also, a counterintuitive increase in protein translation during STF increases unmet energy needs, leading to cell death [12]. Moreover, the $20-40 \%$ reduction in circulating glucose during STF may be enough to kill anoxic tumor cells [85]. Thus, a decrease in nutrient availability during STF makes cancer cells more vulnerable to any challenge, including chemotherapy. However, overconsumption after a STF period might accelerate tumor growth, due to high glucose conditions and increased glycolysis [86].

\section{Reactive oxygen species and DNA damage}

Chemotherapeutic agents inflict oxidative stress and DNA damage upon healthy cells, which are underlying mechanisms of toxicity $[44,87]$. STF dampens oxidative stress in healthy cells by down-regulating metabolic rate and increasing scavenging of reactive oxygen species (ROS), which may contribute to DSR [33, 44]. As serum glucose levels decrease during STF, fatty acids serve as the main energy source. Beta-oxidation of fatty acids produces ketone bodies, which can be used as an alternative/additional fuel. Ketone bodies can also activate pathways involved in protection against ROS [88]. Moreover, STF presumably activates DNA repair processes in healthy cells [22]. For example, in mice fasted for $24 \mathrm{~h}$ before high dose infusion of etoposide, less DNA damage was seen in small intestinal stem cells $3 \mathrm{~h}$ after the infusion compared to mice who ate ad libitum. As $1.5 \mathrm{~h}$ post-treatment DNA damage was similar, DNA repair was likely more efficient in healthy cells due to STF [21].

In contrast, tumor cells exhibit increased ROS production if chemotherapy is combined with STF in vitro [12]. In breast cancer cells cultured in low glucose medium or serum of fasting mice, a 20-fold increase in DNA damage was seen in response to chemotherapy, as compared to cells cultured in regular medium or in serum of ad libitum fed mice [12].

\section{Immune competence}

Chemotherapy causes bone marrow toxicity and depletion of circulating immune cells, especially myeloid cell depletion [89, 90]. Fasting protects hematopoietic stem cells and circulating immune cells from the detrimental effects of chemotherapy in mice [22, 91]. Additionally, more efficient immunity as a result of STF presumably causes a lower rate of infections and febrile neutropenia as well [92].

On the other hand, fasting improves the therapeutic effect of chemotherapy on the tumor possibly through cellular immunity in mice, as this effect is nullified in nu/nu mice, which lack T cells $[40,93]$. Thus, STF may promote immunity and presentation of tumor-associated antigens (TAA), which promote efficient antitumor immunity contributing to increased efficacy of chemotherapy [94].

\section{From animal models to the clinic}

Preclinical data documenting the benefits of STF is abundant and promising. However, words of caution are 
appropriate regarding its application in patients with cancer. For instance, preclinical studies show severe, albeit transient, weight loss in animal models $(20-40 \%$ of total bodyweight after 24-48 h of fasting [12, 19, 23, 39, 95]. In contrast, the impact of a few days of fasting on bodyweight of humans appears far more modest $(\sim 1 \mathrm{~kg}$ per day, largely water loss) [26], which is probably explained by metabolic differences between humans and mice [95]. This is reassuring in the context of safety. However, it may also mean that humans need to fast for a (much) longer period of time than mice to obtain the same benefits (see discussion below). Therefore, carefully controlled clinical trials monitoring tumor growth as well as adverse effects of distinct dietary regimes are required before fasting mimicking diets (FMDs) can be applied in clinical practice.

\section{Metabolic risk factors for cancer}

Obesity is associated with an increased risk of developing several cancers, such as breast cancer, colon cancer, ovarian cancer, endometrial cancer and thyroid cancer $[96,97]$ and IGF-1 levels are positively associated with the risk of developing breast and prostate cancer [98, 99]. Moreover, obesity and high levels of insulin and IGF-1, as well as having diabetes mellitus are associated with worse survival in cancer [100-103]. Obese subjects are often hyperglycemic and hyperinsulinemic, as a result of insulin resistance. Although circulating levels of total (free + bound) IGF-1 are normal or even low in obese subjects, levels of free (bioactive) IGF-1 are higher than in lean subjects [104]. Both insulin and free IGF-1 can bind the IGF-1R and IR-A [105] and activate the Ras/MAPK and PI3K/AKT pathway, through which cell proliferation is stimulated and apoptosis is inhibited, respectively [106]. Moreover, preclinically, obesity is associated with macrophage accumulation in adipose tissue resulting in an immune suppressive microenvironment [107]. These metabolic mechanisms may explain the increased risk of cancer as well as the worse prognosis of several cancers in obese subjects.

\section{Clinical studies of fasting}

Voluntary fasting has been performed for many centuries and purposes, such as religious, ethical and cosmetic $[26,108]$. Hippocrates was probably one of the first advocates of fasting for medical purposes (he recommended to fast during sickness). Since then, several doctors advised their patients to listen to their 'fasting instinct' (the natural loss of appetite during disease). Scientific research on the biomedical effects of fasting was performed from the late nineteenth century on, when several non-obese humans fasted for 20-40 days [26]. The first clinical study of medical fasting for the treatment of obesity was performed in 1915 [109]. The authors reported that short periods of four to six days of fasting is a safe and effective method for reducing bodyweight in obese humans. Since that time several studies were performed in obese subjects, with the longest fasting period lasting 382 days (!) [110, 111]. Fasting therapy was observed to be generally safe and well tolerated. Only mild side effects were reported, including headaches, dizziness, nausea, dyspepsia and fatigue [109-114]. However, in rare cases fasting for periods longer than 2 weeks was fatal in obese subjects with comorbidities as cardiac disease or diabetes mellitus [26, 115-117], and in one rare case a 53-day fast caused Wernicke encephalopathy in a patient with a lymphoma [118]. Additionally, fasting is not suitable for patients with rare metabolic illnesses such as glycogen storage disease or disorders of gluconeogenesis [119]. Benefits of fasting are improved cardiovascular risk factors, such as a decrease in blood pressure, improvement of lipid profile and insulin sensitivity, and weight loss in obese and non-obese subjects [114, 120]. The weight loss during STF is approximately $0.9 \mathrm{~kg}$ per day and decreases during prolonged fasting to $0.3 \mathrm{~kg}$ per day by the third week $[26,121]$. Various studies examined the potential of fasting in the treatment of mood disorders, rheumatic diseases, asthma, chronic pain syndromes, hypertension, and metabolic syndrome [122, 123]. For example, a large cohort study of more than 2000 subjects with chronic illness and pain syndromes, who used a very low-calorie diet of $350 \mathrm{kcal}$ per day for 7 days, showed an increase in quality of life without any serious side effect [122]. In healthy subjects, STF by 3 cycles of a fasting mimicking diet (FMD) reduces common risk factors for cardiovascular diseases, diabetes and ageing, such as lowering blood pressure, body weight, glucose, triglycerides and cholesterol [124]. Additionally, STF may improve clinical outcome in patients undergoing a partial liver resection and may prevent acute kidney injury after cardiac surgery $[125,126]$.

\section{Metabolic changes during STF in humans}

STF has profound metabolic effects in humans [127]. Serum glucose levels drop after a few hours and are maintained at a lower level by endogenous glucose production, stimulated by glucagon. Glycogen storage capacity is limited so that stores are virtually depleted after $24 \mathrm{~h}$. From then on, gluconeogenesis provides the brain with glucose as its major fuel source. Fatty acids are the primary fuel for the rest of the body. Beta-oxidation of fatty acids produces ketone bodies, which can serve as auxiliary energy source for the brain and the rest of the body. Insulin levels decrease rapidly and IGF-1 decreases dramatically after $36-72 \mathrm{~h} \mathrm{[41].} \mathrm{Since} \mathrm{the} \mathrm{liver} \mathrm{is} \mathrm{resist-}$ ant to GH during prolonged fasting, IGF-1 production is profoundly reduced [128]. Diminished negative feedback 
control through reduction of circulating insulin and IGF-1 causes plasma GH levels to increase [129, 130]. IGF binding proteins, which regulate the bio-availability of IGF-1, change during fasting as well [41, 131, 132]. IGF-BP3 levels decrease, while IGF-BP1 levels increase 5-10-fold [133]. The decrease of IGF-I, downregulates the Ras/MAPK and PI3K/Akt pathways, through which cell proliferation is stimulated and apoptosis inhibited $[12,19]$. Moreover, fasting down-regulates the hypothalamus-pituitary-thyroid axis activity. It particularly lowers triiodothyronine (T3), while thyroid stimulating hormone (TSH) and free thyroxine (fT4) are slightly decreased or not affected [134]. Clinical research shows that fasting periods longer than $48 \mathrm{~h}$ are required to facilitate a robust decrease in IGF-1 levels [41]. Therefore, it is likely that the positive effects of STF will be enhanced if the period of fasting is prolonged. A low sugar, low protein FMD may be an alternative to ease the burden of fasting, as it mimics the effects of STF on metabolism [91].

\section{Clinical studies of STF during chemotherapy}

To date, a few small clinical studies in humans exploring the effects of STF combined with chemotherapy have been published (Table 2) [22, 131, 135-138]. The design and results of these studies in humans are summarized below.

In a case series from the University of Southern California (USC), 10 patients with distinct malignancies fasted in combination with docetaxel, carboplatin, paclitaxel and/or gemcitabine [136, 139]. Seven female and three male patients, with a median age of 61 years, diagnosed with breast $(N=4)$, prostate $(N=2)$, esophagus, non-small cell lung cancer, uterus and ovary cancer were described. Patients fasted for $48-140 \mathrm{~h}$ prior to, and 556 after commencing chemotherapy. Six of the ten patients fasted alternately during the chemotherapy cycles (the other four fasted every cycle) and side effects were compared between cycles combined with STF and chemotherapy alone. Side effects were scored according to the Common Terminology Criteria for Adverse Events (CTCAE) 4.0. Besides hunger and dizziness, fasting had no significant side effects. The authors reported a decrease in chemotherapy-induced side effects, including fatigue, weakness, vomiting and diarrhea, when chemotherapy was combined with STF compared to chemotherapy alone. In five patients the tumor volume (evaluated with PET or PET-CT) or tumor markers (PSA or CA-125) were evaluated. STF did not diminish chemotherapy-induced reduction of tumor volume and tumor markers, suggesting that STF did not interfere with the efficacy of chemotherapy.

In the King Fahad Medical City a clinical trial (NCT00757094) was conducted to evaluate the safety and feasibility of combining chemotherapy and intermittent fasting (including liquids) during the Ramadan [135]. Eleven patients, with distinct types of malignancies, received one gift of chemotherapy. Side effects and blood counts were compared with values measured in response to a similar dose of chemotherapy, given 2 weeks after the end of Ramadan. The authors concluded that combining fasting and chemotherapy during the month of Ramadan was well tolerated and safe. Side effects of chemotherapy tended to be less. However, because the study group was small, no statistics were performed. Moreover, due to the short fasting period (approximately $12 \mathrm{~h}$ ), major benefits may not be expected, as IGF-1 levels will evidently not be reduced [140].

We performed a randomized pilot study (NCT01304251) to evaluate the effects of short-term fasting on tolerance to (neo) adjuvant chemotherapy in HER2-negative breast cancer patients in the Leiden University Medical Center (LUMC) [131]. Eligible patients had stage II/III breast cancer and received (neo)-adjuvant TAC (docetaxel/doxorubicin/cyclophosphamide) chemotherapy. Patients were randomized to fast $24 \mathrm{~h}$ before and $24 \mathrm{~h}$ after chemotherapy, or to eat according to the guidelines for healthy nutrition. Metabolic parameters (glucose, insulin and IGF-1) at baseline and immediately before chemotherapy infusion -when patients in the STF group had fasted for $24 \mathrm{~h}$ - were compared. Toxicity in the two groups was compared as well. Additionally, chemotherapy-induced DNA damage was quantified in peripheral blood mononuclear cells (PBMCs) by the level of $\gamma-\mathrm{H} 2 \mathrm{AX}$, as determined by flowcytometry. Thirteen patients were included, of whom seven were randomized to the STF arm. STF was well tolerated in our study. Plasma glucose levels increased and insulin levels remained constant in response to STF. We inferred that this phenomenon was the result of the concomitant use of dexamethasone, which was administered as an anti-emetic, for reduction of fluid retention and dampening of hypersensitivity reactions in response to docetaxel. Circulating IGF-1 levels were only modestly reduced in the study, which could be due to the use of dexamethasone as well $[141,142]$ or to the relatively short duration $(24 \mathrm{~h})$ of fasting prior to chemotherapy. Non-hematological toxicity did not differ between the groups. However, mean erythrocyte- and thrombocyte counts 7 days post-chemotherapy were significantly higher in the STF group compared to the non-STF group. Levels of $\gamma$-H2AX were significantly increased 30 min post-chemotherapy in CD45+CD3- cells in non-STF, but not in STF patients [131]. This study provides evidence that STF attenuates bone marrow toxicity in these patients and reduces chemotherapy-induced DNA damage in PBMCs and/or accelerates its recovery. 


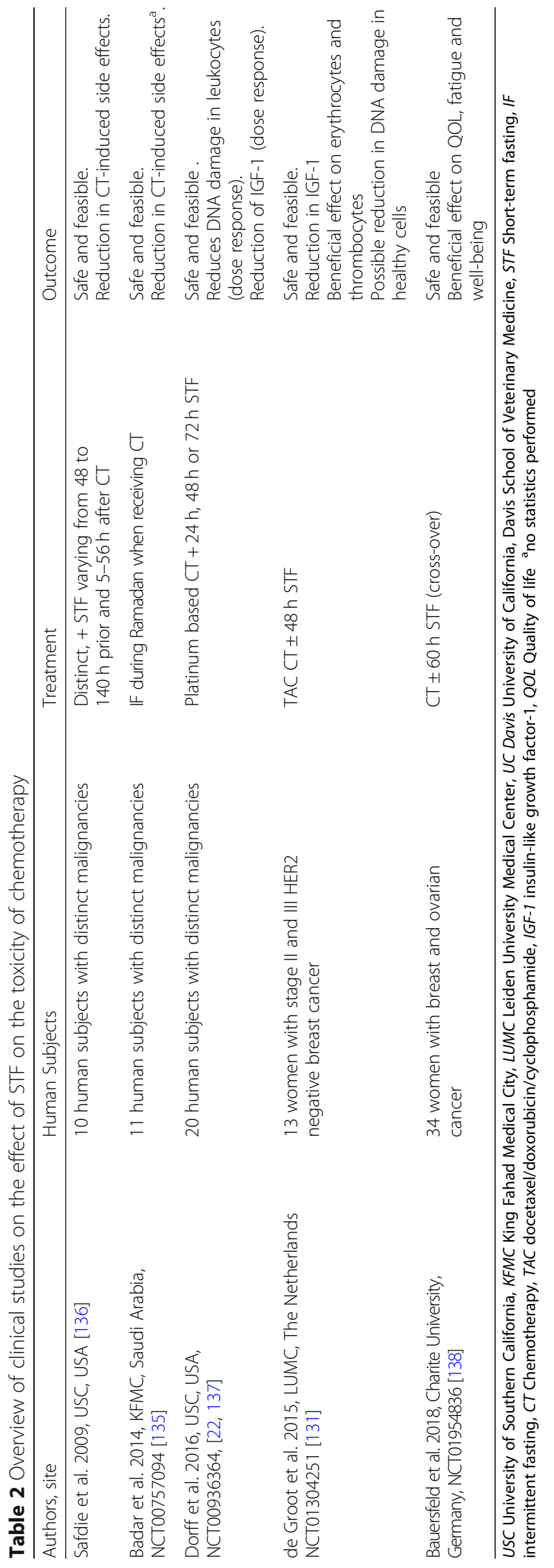


Moreover, Dorff et al. reported results from a dose-escalating phase I study (NCT00936364), wherein 20 human subjects with distinct malignancies were treated with platinum-based chemotherapy combined with 24,48 or $72 \mathrm{~h} \mathrm{STF}$ to identify the optimal fasting duration [22, 137]. Eligible patients had distinct cancer types for which platinum-based combination chemotherapy was given with curative or palliative intent. Metabolic parameters (glucose, insulin, IGF-1 and IGF-BP1) at baseline and immediately before chemotherapy were compared. Moreover, toxicities and chemotherapy-induced DNA damage in PBMCs (determined by the COMET assay) between the three groups were compared. Twenty patients were included, 6 in the $24 \mathrm{~h}$ group and 7 in the 48 and $72 \mathrm{~h}$ group. The fasting was feasible and fasting-related toxicities were limited to grade 1 according CTCAE 4.0. The authors reported that $72 \mathrm{~h}$ of STF was associated with normal lymphocyte counts and maintenance of a normal lineage balance in white blood counts (lymphoid/myeloid ratio) after 2 cycles of chemotherapy, while $24 \mathrm{~h}$ STF was not [22]. IGF-1 levels decreased by 30,33 and $8 \%$ in the 24,48 and $72 \mathrm{~h}$ fasting cohorts, respectively, after the first fasting period. Additionally, the COMET assay showed reduced DNA damage $24 \mathrm{~h}$ after chemotherapy in leukocytes from subjects who fasted for more than $48 \mathrm{~h}$ compared with subjects fasted for $24 \mathrm{~h}(P=0.08)$.

Finally, Bauerfeld et al. published a randomized cross-over trial (NCT01954836) evaluating the effect of STF on quality of life in breast cancer and ovarian cancer patients treated with chemotherapy [138]. Patients were randomized to fast, using an FMD, $36 \mathrm{~h}$ before and $24 \mathrm{~h}$ after chemotherapy or to eat a normocaloric Mediterranean diet for the first three cycles of chemotherapy. After three cycles the patient crossed over to the other group of nutrition (Mediterranean diet or fasting). The design of the study allows intra-individual comparisons regarding side effects of treatment, but precludes conclusions as efficacy of chemotherapy. In total, 50 patients were included in the study, but only 34 were analyzed because of early study discontinuation. The fasting was safe and feasible and five patients (14.7\%) continued fasting after three cycles and did not cross over to the normocaloric diet. The authors concluded that STF led to a better tolerance to chemotherapy with less compromised quality of life (QOL) and reduced fatigue within the 8 days after chemotherapy. Moreover, 31 patients declared that they would fast again during chemotherapy, while only 3 patients declared that they would not fast again during chemotherapy.

These first clinical studies lack enough power to draw definite conclusions. However, the first results suggest that
STF is safe, while it reduces toxicity of chemotherapy. Large scale randomized studies are required to get more insight in the benefits of STF in cancer treatment in humans.

\section{Ongoing studies}

The first clinical studies have shown that STF combined with chemotherapy is safe and feasible in small patient groups [131, 136, 138]. Moreover, STF may reduce chemotherapy-induced toxicity. Additionally, chemotherapy-induced DNA damage in healthy cells may be decreased due to STF. However, large randomized clinical studies are required to generate (more) insight and validate the possible benefits of STF during chemotherapy. In Table 3, an overview is shown of the ongoing trials with STF combined with cancer treatment.

One study to date investigates the effects of STF on the effects radiotherapy. This randomized study (NCT01754350) conducted in Johann Wolfgang Goethe University Hospitals, includes patients with recurrent glioblastoma or gliosarcoma. The intervention entails 3 days of STF and 6 days of ketogenic diet during re-irradiation. The primary endpoint of the study is progression free survival.

A phase II study (NCT01802346), ongoing in the University of Southern California, examines the effects of an FMD on toxicity of chemotherapy in patients with breast and prostate cancer.

The phase II/III study (NCT02126449) from the LUMC, investigates the effects of STF using an FMD on toxicity (phase II part) and efficacy (phase III part) of neo-adjuvant AC-T or FEC-T chemotherapy. In this study prophylactic dexamethasone is omitted in the FMD arm during the AC and FEC chemotherapy cycles to reduce its potentially counteractive metabolic effects. Final results of the study are awaited [68]. The same FMD will be used to investigate the effect on circulating tumor cells in non-small cell lung cancer during treatment with carboplatin, pemetrexed and pembrolizumab.

Another FMD, described by Bauerfeld [138], is tested in two studies (NCT02710721, NCT03162289) conducted in the Charité University in Berlin, one in advanced metastatic prostate cancer and another in ovarian or breast cancer. Primary endpoint of both studies is QOL.

Finally, three studies (NCT03340935, NCT03595540 and NCT03709147) investigate the feasibility and effect of a 5-day FMD (approximately $700 \mathrm{kcal}$ a day) on chemotherapy in distinct tumors and distinct chemotherapy regimens.

\section{Discussion and clinical implications}

Clinical research evaluating the potential of STF is still in its infancy and more research is needed as the exact 


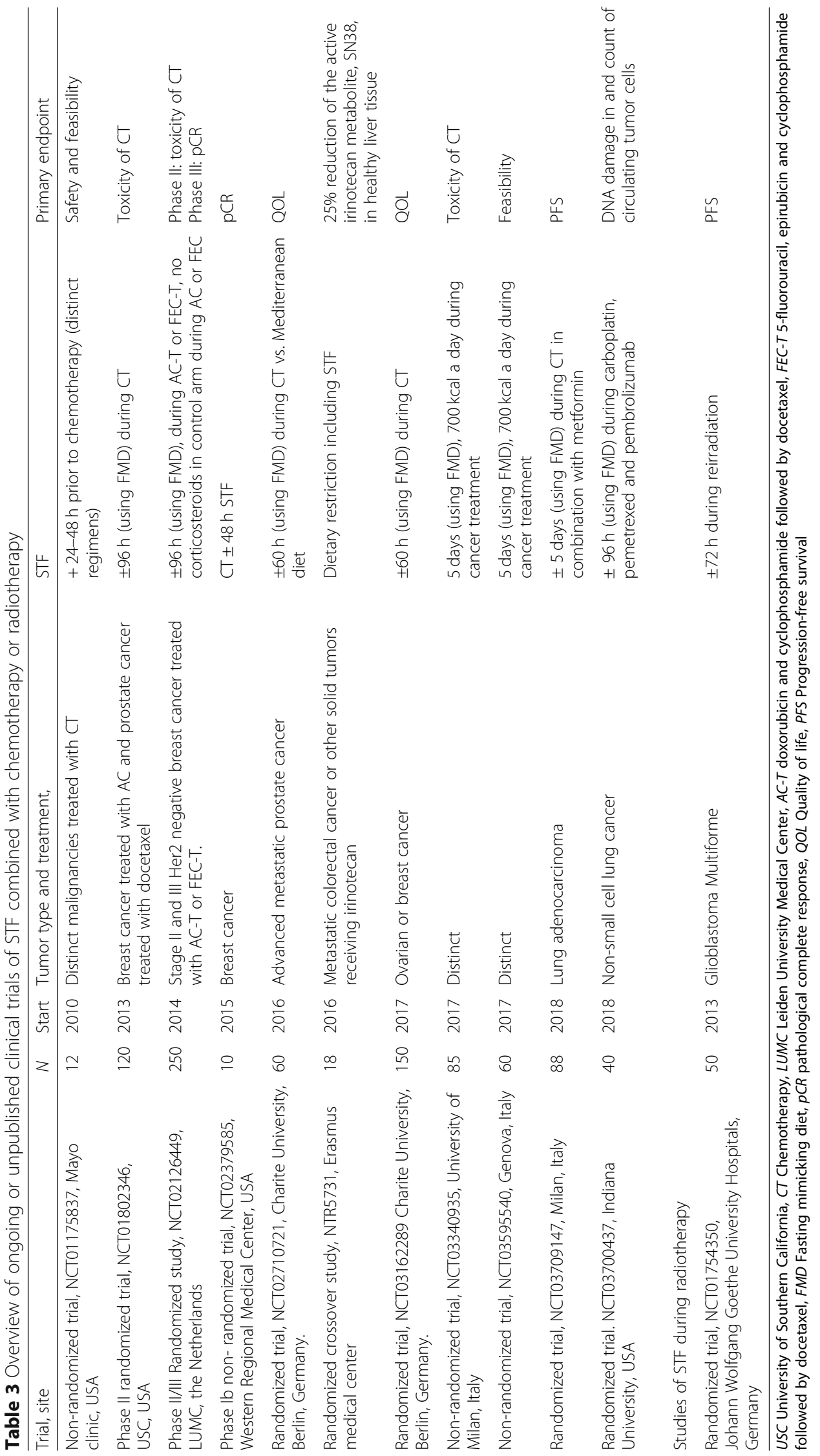


mechanism and effects are not established yet. Remaining questions are: is STF clinically effective in patients with solid tumors, in which tumors is STF effective, which markers are useful for prediction and monitoring of efficacy, what is the optimal length and timing of STF and refeeding, is STF safe in all patients, what is the optimal composition of an FMD, how can we increase patient's compliance?

STF may be an affordable and safe intervention - at least in patients without severe weight loss or malnutrition -, which potentially dampens the side effects of chemotherapy, radiotherapy and TKI's, while reinforcing their efficacy. Furthermore, it is potentially effective in a wide variety of tumors, although there is evidence that tumors with PI3K mutations or highly active AMPK are not sensitive [65, 82]. Reduction of side effects would improve quality of life and potentially reduce costs of hospitalization and the use of drugs such as anti-emetics or antibiotics. Moreover, STF may broaden the therapeutic window of cancer treatments, allowing for an increase of the dosage of (chemo) therapeutic agents, thereby enhancing their efficacy. However, STF might be only feasible in chemotherapeutic regimens characterized by: 1) bolus infusions on one day, to keep the fasting period short, 2) a long interval between two cycles, to ensure sufficient recovery time between cycles and 3) low dose or no use of corticosteroids, to avoid hyperglycemia, which might interfere with the benefits of STF [131].

Patients at risk for malnutrition or cachexia may not be candidates for STF, as it may be unsafe to further limit nutrient intake in these patients for even a short time [27]. However, notably, in preclinical setting caloric restriction showed even preservation of muscle strength in cancer cachexia [143]. Therefore, robust clinical trials are needed to establish the safety and efficacy of FMD in patients at high risk of cachexia.

Close monitoring of patients by nutritionists with expertise in fasting may be needed to increase compliance in future studies and to prevent patients unacceptable weight loss. Moreover, in our opinion, STF or FMDs should only be applied in the context of clinical research in patients with cancer until there is robust evidence for their safety and benefits.

\section{Conclusion}

Abundant and convincing preclinical evidence shows that STF can decrease toxicity and simultaneously increase efficacy of a wide variety of chemotherapeutic agents. Preclinical data suggesting that STF can enhance the effects of radiotherapy and TKIs are promising as well. In clinical studies, STF emerges as a promising strategy to enhance the efficacy and tolerability of chemotherapy. It appears safe as an adjunct to chemotherapy in humans, and it may reduce side effects and DNA damage in healthy cells in response to chemotherapy. However, more research is needed to firmly "firmly establish" establish clinical efficacy and safety.

\section{Abbreviations \\ AMPK: AMP-activated protein kinase; CTCAE: Common Terminology Criteria for Adverse Events; DSR: differential stress resistance; DSS: differential stress sensitization; FMD: fasting mimicking diet; fT4: free thyroxine; GH: growth hormone; IGF-1: insulin-like growth factor-1; IGF-1R: IGF-1 receptor; IR- A: Insulin receptor isoform A; LID : liver Igfi gene deletion; LUMC: Leiden University Medical Center; MAPK: mitogen-activated protein kinase; PBMCs: peripheral blood mononuclear cells; PI3K: phosphatidylinositol-3- kinase; ROS: reactive oxygen species; STF: short-term fasting; T3: lowers triiodothyronine; TKIs: tyrosine kinase inhibitors; TSH: thyroid stimulating hormone; USC: University of Southern California}

\section{Acknowledgements \\ None.}

Funding

This work was supported by a grant from Pink Ribbon (2012.WO31.C155).

Availability of data and materials

Not applicable.

\section{Authors' contributions}

All the authors contributed for the preparation of this manuscript. S.G. wrote the review article, were responsible for the figure and legend, final editing, and preparation of the manuscript for submission. HP, JH and JK critical revised the manuscript. All authors read and approved the final article.

Ethics approval and consent to participate

Not applicable.

Consent for publication

Not applicable.

Competing interests

The authors declare that they have no competing interests.

\section{Publisher's Note}

Springer Nature remains neutral with regard to jurisdictional claims in published maps and institutional affiliations.

\section{Author details}

${ }^{1}$ Department of Medical Oncology, Leiden University Medical Center, Albinusdreef 2, P.O. Box 9600, 2300RC Leiden, The Netherlands. ${ }^{2}$ Department of Endocrinology, Leiden University Medical Center, P.O. Box 9600, 2300RC, Leiden, The Netherlands.

Received: 23 January 2019 Accepted: 22 April 2019

Published online: 22 May 2019

\section{References}

1. Dirx MJ, Zeegers MP, Dagnelie PC, van den Bogaard T, van den Brandt PA. Energy restriction and the risk of spontaneous mammary tumors in mice: a meta-analysis. Int J Cancer. 2003;106(5):766-70.

2. TANNENBAUM A, SILVERSTONE $\mathrm{H}$. Effect of limited food intake on survival of mice bearing spontaneous mammary carcinoma and on the incidence of lung metastases. Cancer Res. 1953;13(7:1):532-6.

3. De Lorenzo MS, Baljinnyam E, Vatner DE, Abarzua P, Vatner SF, Rabson AB. Caloric restriction reduces growth of mammary tumors and metastases. Carcinogenesis. 2011;32(9):1381-7.

4. Mai V, Colbert LH, Berrigan D, Perkins SN, Pfeiffer R, Lavigne JA, et al. Calorie restriction and diet composition modulate spontaneous intestinal tumorigenesis in $\mathrm{Apc}(\mathrm{min})$ mice through different mechanisms. Cancer Res. 2003;63(8):1752-5 
5. Lv M, Zhu X, Wang H, Wang F, Guan W. Roles of caloric restriction, ketogenic diet and intermittent fasting during initiation, progression and metastasis of cancer in animal models: a systematic review and metaanalysis. PLoS One. 2014;9(12):e115147.

6. Colman RJ, Anderson RM, Johnson SC, Kastman EK, Kosmatka KJ, Beasley TM, et al. Caloric restriction delays disease onset and mortality in rhesus monkeys. Science. 2009;325(5937):201-4.

7. Renehan AG, Zwahlen M, Minder C, O'Dwyer ST, Shalet SM, Egger M. Insulin-like growth factor (IGF)-I, IGF binding protein-3, and cancer risk: systematic review and meta-regression analysis. Lancet. 2004;363(9418): 1346-53.

8. Ravussin E, Redman LM, Rochon J, Das SK, Fontana L, Kraus WE, et al. A 2year randomized controlled trial of human caloric restriction: feasibility and effects on predictors of health span and longevity. J Gerontol A Biol Sci Med Sci. 2015;70(9):1097-104.

9. Walford RL, Mock D, Verdery R, MacCallum T. Calorie restriction in biosphere 2: alterations in physiologic, hematologic, hormonal, and biochemical parameters in humans restricted for a 2-year period. J Gerontol A Biol Sci Med Sci. 2002:57(6):B211-24.

10. Racette SB, Weiss EP, Villareal DT, Arif H, Steger-May K, Schechtman KB, et al. One year of caloric restriction in humans: feasibility and effects on body composition and abdominal adipose tissue. J Gerontol A Biol Sci Med Sci. 2006;61(9):943-50.

11. Masoro EJ. Overview of caloric restriction and ageing. Mech Ageing Dev. 2005;126(9):913-22.

12. Lee C, Raffaghello L, Brandhorst S, Safdie FM, Bianchi G, Martin-Montalvo A, et al. Fasting cycles retard growth of tumors and sensitize a range of cancer cell types to chemotherapy. Sci. Transl. Med. 2012;4(124):124ra27.

13. Safdie F, Brandhorst S, Wei M, Wang W, Lee $C$, Hwang $S$, et al. Fasting enhances the response of glioma to chemo- and radiotherapy. PLoS One. 2012;7(9):e44603.

14. Bianchi G, Martella R, Ravera S, Marini C, Capitanio S, Orengo A, et al. Fasting induces anti-Warburg effect that increases respiration but reduces ATP-synthesis to promote apoptosis in colon cancer models. Oncotarget. 2015;6(14):11806-19.

15. Shim HS, Wei M, Brandhorst S, Longo VD. Starvation promotes REV1 SUMOylation and p53-dependent sensitization of melanoma and breast cancer cells. Cancer Res. 2015;75(6):1056-67.

16. Di Biase S, Longo VD. Fasting-induced differential stress sensitization in cancer treatment. Mol Cell Oncol. 2016;3(3):e1117701.

17. Di Biase S, Shim HS, Kim KH, Vinciguerra M, Rappa F, Wei M, et al. Fasting regulates EGR1 and protects from glucose- and dexamethasone-dependent sensitization to chemotherapy. PLoS Biol. 2017;15(3):e2001951.

18. Brandhorst S, Wei M, Hwang S, Morgan TE, Longo VD. Short-term calorie and protein restriction provide partial protection from chemotoxicity but do not delay glioma progression. Exp Gerontol. 2013;48(10):1120-8.

19. Raffaghello L, Lee C, Safdie FM, Wei M, Madia F, Bianchi G, et al. Starvationdependent differential stress resistance protects normal but not cancer cells against high-dose chemotherapy. Proc Natl Acad Sci U S A. 2008;105(24): 8215-20.

20. Huisman SA, Bijman-Lagcher W, IJzermans JN, Smits R, de Bruin RW. Fasting protects against the side effects of irinotecan but preserves its anti-tumor effect in Apc15lox mutant mice. Cell Cycle. 2015;14(14):2333-9.

21. Tinkum KL, Stemler KM, White LS, Loza AJ, Jeter-Jones S, Michalski BM, et al. Fasting protects mice from lethal DNA damage by promoting small intestinal epithelial stem cell survival. Proc Natl Acad Sci U S A. 2015;112(51): E7148-E54.

22. Cheng CW, Adams GB, Perin L, Wei M, Zhou X, Lam BS, et al. Prolonged fasting reduces IGF-1/PKA to promote hematopoietic-stem-cell-based regeneration and reverse immunosuppression. Cell Stem Cell. 2014;14(6): 810-23.

23. Huisman SA, de BP, Ghobadi Moghaddam-Helmantel IM, IJzermans JN, Wiemer EA, Mathijssen RH, et al. Fasting protects against the side-effects of irinotecan treatment but does not abrogate anti-tumor activity in mice. Br. J Pharmacol. 2015

24. Franny Jongbloed SAH, Harry van Steeg, Jeroen L.A. Pennings, Jan N.M. IJzermans, Martijn E.T. Dollé and Ron W.F. de Bruin. The transcriptomic response to irinotecan in colon carcinoma bearing mice preconditioned by fasting. Oncotarget. 2019.

25. Schumacher B, Garinis GA, Hoeijmakers JH. Age to survive: DNA damage and aging. Trends Genet. 2008;24(2):77-85.
26. Kerndt PR, Naughton JL, Driscoll CE, Loxterkamp DA. Fasting: the history, pathophysiology and complications. West J Med. 1982;137(5):379-99.

27. Caccialanza R, De Lorenzo F, Gianotti L, Zagonel V, Gavazzi C, Farina G, et al. Nutritional support for cancer patients: still a neglected right? Support Care Cancer. 2017;25(10):3001-4.

28. Caccialanza R, Aprile G, Cereda E, Pedrazzoli P. Fasting in oncology: a word of caution. Nat Rev Cancer. 2019.

29. Arends J, Bachmann P, Baracos V, Barthelemy N, Bertz H, Bozzetti F, et al. ESPEN guidelines on nutrition in cancer patients. Clin Nutr. 2017;36(1):11-48.

30. Arends J, Baracos V, Bertz H, Bozzetti F, Calder PC, Deutz NEP, et al. ESPEN expert group recommendations for action against cancer-related malnutrition. Clin Nutr. 2017;36(5):1187-96.

31. Bishop NA, Guarente L. Genetic links between diet and lifespan: shared mechanisms from yeast to humans. Nat Rev Genet. 2007;8(11):835-44.

32. Fontana $L$, Partridge L, Longo VD. Extending healthy life span--from yeast to humans. Science. 2010;328(5976):321-6.

33. Sohal RS, Weindruch R. Oxidative stress, caloric restriction, and aging. Science. 1996;273(5271):59-63.

34. Hanahan D, Weinberg RA. Hallmarks of cancer: the next generation. Cell. 2011;144(5):646-74.

35. Ward PS, Thompson CB. Metabolic reprogramming: a cancer hallmark even Warburg did not anticipate. Cancer Cell. 2012;21(3):297-308.

36. D'Aronzo M, Vinciguerra M, Mazza T, Panebianco C, Saracino C, Pereira SP, et al. Fasting cycles potentiate the efficacy of gemcitabine treatment in in vitro and in vivo pancreatic cancer models. Oncotarget. 2015.

37. Shi Y, Felley-Bosco E, Marti TM, Orlowski K, Pruschy M, Stahel RA. Starvationinduced activation of ATM/Chk2/p53 signaling sensitizes cancer cells to cisplatin. BMC Cancer. 2012;12:571.

38. Saleh AD, Simone BA, Palazzo J, Savage JE, Sano Y, Dan T, et al. Caloric restriction augments radiation efficacy in breast cancer. Cell Cycle. 2013; 12(12):1955-63.

39. Caffa I, Longo VD, Nencioni A. Fasting plus tyrosine kinase inhibitors in cancer. Aging (Albany. NY). 2015;7(12):1026-7.

40. Pietrocola F, Pol J, Vacchelli E, Rao S, Enot DP, Baracco EE, et al. Caloric restriction mimetics enhance anticancer Immunosurveillance. Cancer Cell. 2016:30(1):147-60.

41. Thissen JP, Ketelslegers JM, Underwood LE. Nutritional regulation of the insulin-like growth factors. Endocr Rev. 1994;15(1):80-101.

42. Lee C, Safdie FM, Raffaghello L, Wei M, Madia F, Parrella E, et al. Reduced levels of IGF-I mediate differential protection of normal and cancer cells in response to fasting and improve chemotherapeutic index. Cancer Res. 2010; 70(4):1564-72

43. Hursting SD, Lavigne JA, Berrigan D, Donehower LA, Davis BJ, Phang JM, et al. Diet-gene interactions in p53-deficient mice: insulin-like growth factor-1 as a mechanistic target. J Nutr. 2004;134(9):2482S-6S.

44. Lee C, Longo VD. Fasting vs dietary restriction in cellular protection and cancer treatment: from model organisms to patients. Oncogene. 2011; 30(30):3305-16.

45. Kirkwood TB, Shanley DP. Food restriction, evolution and ageing. Mech Ageing Dev. 2005;126(9):1011-6.

46. Kirkwood TL, Kapahi P, Shanley DP. Evolution, stress, and longevity. J Anat. 2000;197(Pt 4):587-90.

47. Heilbronn LK, Ravussin E. Calorie restriction and aging: review of the literature and implications for studies in humans. Am J Clin Nutr. 2003; 78(3):361-9.

48. Murray MJ, Murray AB. Anorexia of infection as a mechanism of host defense. Am J Clin Nutr. 1979;32(3):593-6.

49. Exton MS. Infection-induced anorexia: active host defence strategy. Appetite. 1997;29(3):369-83.

50. Giovannucci E, Pollak M, Liu Y, Platz EA, Majeed N, Rimm EB, et al. Nutritional predictors of insulin-like growth factor I and their relationships to cancer in men. Cancer Epidemiol Biomark Prev. 2003;12(2):84-9.

51. Prisco M, Romano G, Peruzzi F, Valentinis B, Baserga R. Insulin and IGF-I receptors signaling in protection from apoptosis. Horm Metab Res. 1999; 31(2-3):80-9.

52. Fontana L, Weiss EP, Villareal DT, Klein S, Holloszy JO. Long-term effects of calorie or protein restriction on serum IGF-1 and IGFBP-3 concentration in humans. Aging Cell. 2008;7(5):681-7.

53. Belfiore A, Malaguarnera R, Vella V, Lawrence MC, Sciacca L, Frasca F, et al. Insulin receptor isoforms in physiology and disease: an updated view. Endocr Rev. 2017;38(5):379-431. 
54. Ketelslegers JM, Maiter D, Maes M, Underwood LE, Thissen JP. Nutritional regulation of insulin-like growth factor-I. Metabolism. 1995;44(10 Suppl 4): 50-7.

55. Henning PC, Scofield DE, Rarick KR, Pierce JR, Staab JS, Lieberman HR, et al. Effects of acute caloric restriction compared to caloric balance on the temporal response of the IGF-I system. Metabolism. 2013;62(2):179-87.

56. Snel M, Wijngaarden MA, Bizino MB, van der Grond J, Teeuwisse WM, van Buchem MA, et al. Food cues do not modulate the neuroendocrine response to a prolonged fast in healthy men. Neuroendocrinology. 2012; 96(4):285-93.

57. Beauloye V, Willems B. de C, V, frank SJ, Edery M, Thissen JP. Impairment of liver GH receptor signaling by fasting. Endocrinology. 2002;143(3):792-800.

58. Leung KC, Doyle N, Ballesteros M, Waters MJ, Ho KK. Insulin regulation of human hepatic growth hormone receptors: divergent effects on biosynthesis and surface translocation. J Clin Endocrinol Metab. 2000;85(12): 4712-20.

59. Yakar S, Liu JL, Stannard B, Butler A, Accili D, Sauer B, et al. Normal growth and development in the absence of hepatic insulin-like growth factor I. Proc Natl Acad Sci U S A. 1999:96(13):7324-9.

60. Anzo M, Cobb LJ, Hwang DL, Mehta H, Said JW, Yakar S, et al. Targeted deletion of hepatic lgf1 in TRAMP mice leads to dramatic alterations in the circulating insulin-like growth factor axis but does not reduce tumor progression. Cancer Res. 2008;68(9):3342-9.

61. Wu Y, Yakar S, Zhao L, Hennighausen L, LeRoith D. Circulating insulin-like growth factor-I levels regulate colon cancer growth and metastasis. Cancer Res. 2002;62(4):1030-5.

62. Kawaguchi T, Takemura G, Kanamori H, Takeyama T, Watanabe T, Morishita K, et al. Prior starvation mitigates acute doxorubicin cardiotoxicity through restoration of autophagy in affected cardiomyocytes. Cardiovasc Res. 2012;96(3):456-65.

63. Withers SS, Kass PH, Rodriguez CO, Jr., Skorupski KA, O'Brien D, Guerrero TA, et al. , Fasting Reduces the Incidence of Delayed-Type Vomiting Associated with Doxorubicin Treatment in Dogs with Lymphoma. Transl. Oncol. 2014.

64. Djiogue S, Nwabo Kamdje AH, Vecchio L, Kipanyula MJ, Farahna M, Aldebasi $Y$, et al. Insulin resistance and cancer: the role of insulin and IGFs. Endocr Relat Cancer. 2013;20(1):R1-R17.

65. Kalaany NY, Sabatini DM. Tumours with PI3K activation are resistant to dietary restriction. Nature. 2009;458(7239):725-31.

66. Zhang $Y$, Moerkens M, Ramaiahgari S, de BH, Price L, Meerman J, et al, Elevated insulin-like growth factor 1 receptor signaling induces antiestrogen resistance through the MAPK/ERK and PI3K/Akt signaling routes. Breast Cancer Res. 2011;13(3):R52

67. de Groot S, Charehbili A, van Laarhoven HW, Mooyaart AL, Dekker-Ensink $N G$, van de Ven S, et al. Insulin-like growth factor 1 receptor expression and IGF1R 3129G > T polymorphism are associated with response to neoadjuvant chemotherapy in breast cancer patients: results from the NEOZOTAC trial (BOOG 2010-01). Breast Cancer Res. 2016;18(1):3.

68. S de Groot RL, MJ Welters, I Ehsan, MP Vreeswijk, VT Smit, H de Graaf, JB Heijns, JE Portielje, AJ van de Wouw, AL Imholz, LW Kessels, S Vrijaldenhoven, A Baars, E Meershoek-Klein Kranenbarg, M Duijm-de Carpentier, E van Leeuwen-Stok, H Putter, VD Longo, JJ van der Hoeven, JW Nortier, H Pijl and JR Kroep. Abstract P1-15-20: Dletary REstriction as an adjunct to neoadjuvant ChemoTherapy for HER2-negative breast cancer: Final results from the DIRECT trial (BOOG 2013-04). American Association for Cancer Research. 2019.

69. Jiang W, Zhu Z, Thompson HJ. Dietary energy restriction modulates the activity of AMP-activated protein kinase, Akt, and mammalian target of rapamycin in mammary carcinomas, mammary gland, and liver. Cancer Res. 2008;68(13):5492-9.

70. Hardie DG. AMP-activated protein kinase: a cellular energy sensor with a key role in metabolic disorders and in cancer. Biochem Soc Trans. 2011;39(1):1-13

71. Mihaylova MM, Shaw RJ. The AMPK signalling pathway coordinates cell growth, autophagy and metabolism. Nat Cell Biol. 2011;13(9):1016-23.

72. Mizushima N. Autophagy: process and function. Genes Dev. 2007;21(22):2861-73.

73. Kroemer G, Marino G, Levine B. Autophagy and the integrated stress response. Mol Cell. 2010;40(2):280-93.

74. Vidal AP, Andrade BM, Vaisman F, Cazarin J, Pinto LF, Breitenbach MM, et al. AMP-activated protein kinase signaling is upregulated in papillary thyroid cancer. Eur J Endocrinol. 2013;169(4):521-8.

75. Zadra G, Batista JL, Loda M. Dissecting the dual role of AMPK in Cancer: from experimental to human studies. Mol Cancer Res. 2015;13(7):1059-72.
76. Hadad SM, Baker L, Quinlan PR, Robertson KE, Bray SE, Thomson G, et al. Histological evaluation of AMPK signalling in primary breast cancer. BMC Cancer. 2009;9:307.

77. Leprivier G, Remke M, Rotblat B, Dubuc A, Mateo AR, Kool M, et al. The eEF2 kinase confers resistance to nutrient deprivation by blocking translation elongation. Cell. 2013;153(5):1064-79.

78. Zheng L, Yang W, Wu F, Wang C, Yu L, Tang L, et al. Prognostic significance of AMPK activation and therapeutic effects of metformin in hepatocellular carcinoma. Clin Cancer Res. 2013;19(19):5372-80.

79. Wang L, Shang Z, Zhou Y, Hu X, Chen Y, Fan Y, et al. Autophagy mediates glucose starvation-induced glioblastoma cell quiescence and chemoresistance through coordinating cell metabolism, cell cycle, and survival. Cell Death Dis. 2018;9(2):213.

80. Sato K, Tsuchihara K, Fujii S, Sugiyama M, Goya T, Atomi Y, et al. Autophagy is activated in colorectal cancer cells and contributes to the tolerance to nutrient deprivation. Cancer Res. 2007;67(20):9677-84.

81. Petibone DM, Majeed W, Casciano DA. Autophagy function and its relationship to pathology, clinical applications, drug metabolism and toxicity. J Appl Toxicol. 2017;37(1):23-37.

82. van Niekerk G, Hattingh SM, Engelbrecht AM. Enhanced therapeutic efficacy in Cancer patients by short-term fasting: the autophagy connection. Front Oncol. 2016;6:242.

83. DeBerardinis RJ, Lum JJ, Hatzivassiliou G, Thompson CB. The biology of cancer: metabolic reprogramming fuels cell growth and proliferation. Cell Metab. 2008;7(1):11-20.

84. Vander Heiden MG, Cantley LC, Thompson CB. Understanding the Warburg effect: the metabolic requirements of cell proliferation. Science. 2009; 324(5930):1029-33.

85. Lankelma J, Kooi B, Krab K, Dorsman JC, Joenje H, Westerhoff HV. A reason for intermittent fasting to suppress the awakening of dormant breast tumors. Biosystems. 2015;127:1-6.

86. Kusuoka O, Fujiwara-Tani R, Nakashima C, Fujii K, Ohmori H, Mori T, et al. Intermittent calorie restriction enhances epithelial-mesenchymal transition through the alteration of energy metabolism in a mouse tumor model. Int Oncol. 2018;52(2):413-23.

87. Chen $Y$, Jungsuwadee $P$, Vore M, Butterfield DA, St Clair DK. Collateral damage in cancer chemotherapy: oxidative stress in nontargeted tissues. Mol Interv. 2007;7(3):147-56.

88. Veech RL. Ketone ester effects on metabolism and transcription. J Lipid Res. 2014;55(10):2004-6.

89. Aapro MS, Bohlius J, Cameron DA, Dal LL, Donnelly JP, Kearney N, et al. 2010 update of EORTC guidelines for the use of granulocyte-colony stimulating factor to reduce the incidence of chemotherapy-induced febrile neutropenia in adult patients with lymphoproliferative disorders and solid tumours. Eur J Cancer. 2011:47(1):8-32.

90. Marij J. Welters, Tetje C. van der Sluis, Hélène van Meir, Nikki M. Loof, Vanessa J. van Ham, Suzanne van Duikeren et al. Vaccination during myeloid cell depletion by cancer chemotherapy fosters robust T-cell responses. Sci Transl Med. 2016.

91. Brandhorst S, Choi IY, Wei M, Cheng CW, Sedrakyan S, Navarrete G, et al. A periodic diet that mimics fasting promotes multi-system regeneration, enhanced cognitive performance, and Healthspan. Cell Metab. 2015;22(1):86-99.

92. Wing EJ, Stanko RT, Winkelstein A, Adibi SA. Fasting-enhanced immune effector mechanisms in obese subjects. Am J Med. 1983;75(1):91-6.

93. Englert JM, Powell JD. Hunger pains: stimulating the appetite of the immune system for Cancer. Cancer Cell. 2016;30(1):13-5.

94. Di Biase S, Lee C, Brandhorst S, Manes B, Buono R, Cheng CW, et al. Fastingmimicking diet reduces $\mathrm{HO}-1$ to promote $\mathrm{T}$ cell-mediated tumor cytotoxicity. Cancer Cell. 2016;30(1):136-46.

95. Jensen TL, Kiersgaard MK, Sorensen DB, Mikkelsen LF. Fasting of mice: a review. Lab Anim. 2013;47(4):225-40.

96. Bhaskaran K, Douglas I, Forbes H. dos-Santos-Silva I, Leon DA, Smeeth L. body-mass index and risk of 22 specific cancers: a population-based cohort study of 5.24 million UK adults. Lancet. 2014;384(9945):755-65.

97. Chan DS, Vieira AR, Aune D, Bandera EV, Greenwood DC, McTiernan A, et al. Body mass index and survival in women with breast cancer-systematic literature review and meta-analysis of 82 follow-up studies. Ann Oncol. 2014;25(10):1901-14.

98. Rowlands MA, Gunnell D, Harris R, Vatten LJ, Holly JM, Martin RM. Circulating insulin-like growth factor peptides and prostate cancer 
risk: a systematic review and meta-analysis. Int J Cancer. 2009;124(10): 2416-29.

99. Endogenous H. Breast Cancer collaborative G, key TJ, Appleby PN, reeves GK, Roddam AW. Insulin-like growth factor 1 (IGF1), IGF binding protein 3 (IGFBP3), and breast cancer risk: pooled individual data analysis of 17 prospective studies. Lancet Oncol. 2010;11(6):530-42.

100. Ferroni P, Riondino S, Laudisi A, Portarena I, Formica V, Alessandroni J, et al. Pretreatment insulin levels as a prognostic factor for breast Cancer progression. Oncologist. 2016;21(9):1041-9.

101. Duggan C, Wang CY, Neuhouser ML, Xiao L, Smith AW, Reding KW, et al. Associations of insulin-like growth factor and insulin-like growth factor binding protein-3 with mortality in women with breast cancer. Int J Cancer. 2013;132(5):1191-200.

102. Meyerhardt JA, Catalano PJ, Haller DG, Mayer RJ, Macdonald JS, Benson AB 3rd, et al. Impact of diabetes mellitus on outcomes in patients with colon cancer. J Clin Oncol. 2003;21(3):433-40.

103. Derr RL, Ye X, Islas MU, Desideri S, Saudek CD, Grossman SA. Association between hyperglycemia and survival in patients with newly diagnosed glioblastoma. J Clin Oncol. 2009;27(7):1082-6.

104. van Kruijsdijk RC, van der Wall E, Visseren FL. Obesity and cancer: the role of dysfunctional adipose tissue. Cancer Epidemiol Biomark Prev. 2009;18(10):2569-78.

105. Vella V, Milluzzo A, Scalisi NM, Vigneri P, Sciacca L. Insulin Receptor Isoforms in Cancer. Int J Mol Sci. 2018;19(11)

106. Pollak M. Insulin, insulin-like growth factors and neoplasia. Best Pract Res Clin Endocrinol Metab. 2008;22(4):625-38.

107. Weisberg SP, McCann D, Desai M, Rosenbaum M, Leibel RL, Ferrante AW Jr. Obesity is associated with macrophage accumulation in adipose tissue. J Clin Invest. 2003;112(12):1796-808.

108. Johnstone AM. Fasting - the ultimate diet? Obes Rev. 2007;8(3):211-22.

109. Folin O, Denis W. On starvation and obesity, with special reference to acidosis. J Biol Chem. 1915;21:183-92.

110. Stewart WK, Fleming LW. Features of a successful therapeutic fast of 382 days' duration. Postgrad Med J. 1973;49(569):203-9.

111. Thomson TJ, Runcie J, Miller V. Treatment of obesity by total fasting for up to 249 days. Lancet. 1966;2(7471):992-6.

112. BLOOM WL. Fasting as an introduction to the treatment of obesity. Metabolism. 1959;8(3):214-20.

113. Drenick EJ, Smith R. Weight Reduction by Prolonged Starvation: Practical Management. Postgrad. Med. 1964;36:A95-100.

114. Franc, oise Wilhelmi de Toledo FG, Audrey Bergouignan, , Stefan Drinda AM. Safety, health improvement and well-being during a 4 to 21-day fasting period in an observational study including 1422 subjects. PLoS One. 2019.

115. Spencer IO. Death during therapeutic starvation for obesity. Lancet. 1968; 1(7555):1288-90.

116. Cubberley PT, Polster SA, Schulman CL. Lactic acidosis and death after the treatment of obesity by fasting. N Engl J Med. 1965;272:628-30.

117. Runcie J, Thomson TJ. Prolonged starvation--a dangerous procedure? $\mathrm{Br}$ Med J. 1970;3(5720):432-5.

118. Brazg J, Ruest A, Law S, Bosoy D. A therapeutic fast for lymphoma resulting in Wernicke encephalopathy. J Emerg Med. 2015;49(4):471-4.

119. Douillard C, Mention K, Dobbelaere D, Wemeau JL, Saudubray JM, Vantyghem MC. Hypoglycaemia related to inherited metabolic diseases in adults. Orphanet J Rare Dis. 2012;7:26.

120. Goldhamer AC, Lisle DJ, Sultana P, Anderson SV, Parpia B, Hughes $B$, et al. Medically supervised water-only fasting in the treatment of borderline hypertension. J Altern Complement Med. 2002;8(5):643-50.

121. Cahill GF Jr, Owen OE. Starvation and survival. Trans Am Clin Climatol Assoc. 1968;79:13-20

122. Michalsen A, Hoffmann B, Moebus S, Backer M, Langhorst J, Dobos GJ. Incorporation of fasting therapy in an integrative medicine ward: evaluation of outcome, safety, and effects on lifestyle adherence in a large prospective cohort study. J Altern Complement Med. 2005;11(4):601-7.

123. Han K, Nguyen A, Traba J, Yao X, Kaler M, Huffstutler RD, et al. A pilot study to investigate the immune-modulatory effects of fasting in steroid-naive mild asthmatics. J Immunol. 2018;201(5):1382-8.

124. Wei M, Brandhorst S, Shelehchi M, Mirzaei H, Cheng CW, Budniak J, et al. Fasting-mimicking diet and markers/risk factors for aging, diabetes, cancer, and cardiovascular disease. Sci Transl Med. 2017;9(377).
125. Zhan C, Dai X, Shen G, Lu X, Wang X, Lu L, et al. Preoperative short-term fasting protects liver injury in patients undergoing hepatectomy. Ann Transl Med. 2018;6(23):449.

126. Grundmann F, Muller RU, Reppenhorst A, Hulswitt L, Spath MR, Kubacki T, et al. Preoperative Short-Term Calorie Restriction for Prevention of Acute Kidney Injury After Cardiac Surgery: A Randomized, Controlled, Open-Label, Pilot Trial. J Am Heart Assoc. 2018;7(6).

127. Cahill G Jr, Felig P, Owen O, Wahren J. Metabolic adaptation to prolonged starvation in man. Nord Med. 1970;83(3):89.

128. Ho KY, Veldhuis JD, Johnson ML, Furlanetto R, Evans WS, Alberti KG, et al. Fasting enhances growth hormone secretion and amplifies the complex rhythms of growth hormone secretion in man. J Clin Invest. 1988;81(4):968-75.

129. Norrelund $\mathrm{H}$. The metabolic role of growth hormone in humans with particular reference to fasting. Growth Hormon IGF Res. 2005;15(2):95-122.

130. Moller L, Dalman L, Norrelund H, Billestrup N, Frystyk J, Moller N, et al. Impact of fasting on growth hormone signaling and action in muscle and fat. J Clin Endocrinol Metab. 2009;94(3):965-72.

131. de Groot S, Vreeswijk MP, Welters MJ, Gravesteijn G, Boei JJ, Jochems A, et al. The effects of short-term fasting on tolerance to (neo) adjuvant chemotherapy in HER2-negative breast cancer patients: a randomized pilot study. BMC. Cancer. 2015;15:652.

132. Maccario M, Aimaretti G, Grottoli S, Gauna C, Tassone F, Corneli G, et al. Effects of 36 hour fasting on GH/IGF-I axis and metabolic parameters in patients with simple obesity. Comparison with normal subjects and hypopituitary patients with severe GH deficiency. Int. J Obes Relat Metab Disord. 2001;25(8):1233-9.

133. Cotterill AM, Holly JM, Wass JA. The regulation of insulin-like growth factor binding protein (IGFBP)-1 during prolonged fasting. Clin. Endocrinol. (Oxf). 1993;39(3):357-62

134. Boelen A, Wiersinga WM, Fliers E. Fasting-induced changes in the hypothalamus-pituitary-thyroid axis. Thyroid. 2008;18(2):123-9.

135. Badar T, Ismail A, AlShanqeeti A. Safety and Feasability of Muslim Fasting While Receiving Chemotherapy. IOSR Journal of Pharmacy. 2014.

136. Safdie FM, Dorff T, Quinn D, Fontana L, Wei M, Lee C, et al. Fasting and cancer treatment in humans: A case series report. Aging (Albany. NY). 2009; 1(12):988-1007

137. Dorff TB, Groshen S, Garcia A, Shah M, Tsao-Wei D, Pham H, et al. Safety and feasibility of fasting in combination with platinum-based chemotherapy. BMC Cancer. 2016;16:360.

138. Bauersfeld SP, Kessler CS, Wischnewsky M, Jaensch A, Steckhan N, Stange R, et al. The effects of short-term fasting on quality of life and tolerance to chemotherapy in patients with breast and ovarian cancer: a randomized cross-over pilot study. BMC Cancer. 2018;18(1):476.

139. Raffaghello L, Safdie F, Bianchi G, Dorff T, Fontana L, Longo VD. Fasting and differential chemotherapy protection in patients. Cell Cycle. 2010; 9(22):4474-6

140. Bouhlel E, Zaouali M, Miled A, Tabka Z, Bigard X, Shephard R. Ramadan fasting and the GH/IGF-1 axis of trained men during submaximal exercise. Ann Nutr Metab. 2008;52(4):261-6.

141. Inder WJ, Jang C, Obeyesekere VR, Alford FP. Dexamethasone administration inhibits skeletal muscle expression of the androgen receptor and IGF-1--implications for steroid-induced myopathy. Clin. Endocrinol. (Oxf). 2010;73(1):126-32.

142. Veldhuis JD, Lizarralde G, Iranmanesh A. Divergent effects of short term glucocorticoid excess on the gonadotropic and somatotropic axes in normal men. J Clin Endocrinol Metab. 1992;74(1):96-102.

143. Levolger S, van den Engel S, Ambagtsheer G, JNM IJ, de Bruin RWF. Caloric restriction is associated with preservation of muscle strength in experimental cancer cachexia. Aging (Albany NY). 2018;10(12):4213-23. 